\begin{tabular}{|c|}
\hline PRE-PRINT (or SUBMITTED) version \\
\hline $\begin{array}{c}\text { Official published paper: } \\
\text { https://onlinelibrary.wiley.com/doi/abs/10.1002/csr.1813 }\end{array}$ \\
\hline $\begin{array}{l}\text { Free online accessible version (with restriction): } \\
\underline{\text { https://rdcu.be/bLxTs }}\end{array}$ \\
\hline
\end{tabular}

\title{
The materiality assessment and stakeholder engagement: A content analysis of sustainability reports
}

\author{
Riccardo Torelli \\ University of Parma - Department of Economics and Management \\ Via J.F. Kennedy, 6 - 43125 Parma (Italy) \\ riccardo.torelli@unipr.it \\ Federica Balluchi \\ University of Parma - Department of Economics and Management \\ Katia Furlotti \\ University of Parma - Department of Economics and Management
}

\begin{abstract}
Materiality is the driver through which companies can select issues to be included in nonfinancial reports favouring expectations of all the stakeholders. The aim of this research is to investigate, under the lens of Stakeholder Theory and Instrumental Stakeholder Theory, the possible relationship between the application of materiality principle in non-financial reports and the engagement of stakeholders, with a preliminary focus on different industries that are characterized by different types of stakeholder. We have subjected to a manual content analysis all the Italian listed companies that published a sustainability/integrated report in the years 2013, 2014, 2015 and 2016 following guidelines of GRI and IIRC (a total of 148 reports). The next statistical analysis highlights, as research finding, the importance of industry and above all of stakeholder engagement in the reporting process, in particular in the materiality analysis, to achieve a high level of materiality application level and a good report quality for stakeholders.
\end{abstract}

Key Words: materiality, stakeholder engagement, sustainability report, content analysis, Stakeholder Theory.

Short running title: Stakeholder Engagement in Materiality Assessment 


\section{Introduction}

The growing attention paid to sustainability, in all its environmental, social, ethical and economic aspects has brought the non-financial reports to be widely use. There are different frameworks and standards that guide the creation process and the content of such reports by defining many key principles; materiality, among these, it's the most significant and complex. This principle represents the driver through which companies can identify and select issues to be included and treated in integrated, sustainability and other voluntary reports favouring expectations and needs of all the stakeholders ${ }^{1}$.

Since the eighties, the studies have begun in order to better understand this concept, how it was used and considered by the final receivers of the document prepared in accordance with the principle itself (Deegan \& Rankin, 1997; Eccles \& Krzus, 2014; Holstrum \& Messier Jr., 1982; Jones et al., 2016; Messier et al., 2005; Vance, 2011). Several works stress the importance of the issue (Murillo \& Lozano, 2006; Porter \& Kramer, 2006; Unerman \& Zappettini, 2014) and others have focused on the determinants of materiality and on the materiality indicators (Brammer \& Pavelin, 2006; Cooke, 1992; Fasan \& Mio, 2017; Hassan \& Ibrahim, 2012; Patten, 2002; Webb et al., 2008). This study starts from the scholar works related to materiality analysis (Font et al., 2016; Pfitzer et al., 2013) and to the connected set of stakeholder expectations. Some researchs investigated the crucial issue, for sustainability and integrated report, of materiality analysis to achieve the highest level of coincidence between the interests of all stakeholders (Boesso \& Kumar, 2009; Unerman \& Bennett, 2004) and of the companies themselves (Adams, 2004; Calabrese et al., 2105; de Villiers \& van Staden, 2010; O’Dwyer et al., 2005).

Calabrese et al. (2015) and Basu \& Palazzo (2008), to name a few, have opened spaces to new studies and investigations about this issue and in particular on materiality assessment in sustainability reporting and on motives behind this type of activities, measuring impacts and determining links to stakeholder needs.

We aim to fill a gap of investigation about the possible contribution that different stakeholder engagement processes could bring to the process of materiality analysis and then to the related production of the non-financial reports. The direct involvement of all company stakeholders (stakeholder engagement) could be the way to really understand stakeholder expectations and needs, and to make the companies able to appropriately define the report content.

Altough Stakeholder Theory (Freeman, 1984) and the more recent Instrumental Stakeholder Theory (Jones, 1995) are a widley used theories in this field of research and the need to meet as more as possible the information requests and expectation of all the stakeholder groups is highly investigated, the process of involment of these stakeholders has not been deeply analysed. Then the aim of this paper is to investigate, through a manual content analysis and the lens of these theories the relationship between stakeholder engagement (considering different types and groups of them with the focus on different industries) and the application level of materiality principle.

The paper is divided into three main parts: in the first part we propose a literature review and some theoretical foundations; the second part shows the methodology of the research, the results of the empirical analysis and a discussion of them; in the third and last part, we offer some final considerations.

\footnotetext{
1 "The report should cover aspects that: reflect the organization's significant economic, environmental and social impacts; or substantively influence the assessments and decision of stakeholders" (GRI, 2013).

"A matter is material if it could substantively affect the organization's ability to create value in the short, medium or long term" (IIRC \& IFAC, 2015).
} 


\section{Literature Review and Theoretical Pillars}

Materiality can be defined as a long-term focus on the issues that make difference to both an organisation's performance and management priorities both the information needed to make sound judgements (Sustainability Accounting Standard Board, 2013). According to the IIRC "a matter is material if it could substantively affect the organization's ability to create value in the short, medium or long term" (IIRC, 2013). Materiality is one of the most significant principle for companies that desire to disclose their Corporate Social Responsibility (CSR). It is the driver through which companies can identify and select issues to be included and treated in integrated and sustainability reports favouring expectations and needs of all the stakeholders; "the report should cover aspects that: reflect the organization's significant economic, environmental and social impacts; or substantively influence the assessments and decision of stakeholders" (GRI, 2013). CSR, in fact, can be defined as the responsibilities of a company towards society and the environment, "the process of communicating the social, ethical and environmental effects of organisations' economic actions to particular interest groups within society and to society at large" (Gray et al., 1987). This responsibility is marked by the economic, legal, ethical and discretionary expectations that society has of organisations (Font et al., 2016). The formal commitment to inform and involve stakeholders necessitates an adequate flow of communication through suitable channels, focusing on relevant content. CSRD plays a key role in this commitment, and transparent reliable information is also widely considered important for legitimacy. Therefore, in order to explain their CSR, companies have to define instrument of accountability because "CSR and CSR reporting cannot be understood in isolation of each other or the organizational functions and operations on which they impinge" (Adams, 2008). Therefore, responsibility is the process of accepting the expectations placed by society and accountability is the duty of providing an account for meeting those expectations (Gray et al., 1997).

The widespread literature existing about materiality move from the studies related to the CSR disclosure and, among these, to the ones' devoted to CSR engagement in particular.

Several studies analyse the importance of a good CSR disclosure. Some researches analyse the importance of gaining returns from companies' CSR, such as company reputation, customer loyalty and customer-company identification (Calabrese et al., 2015; Du, Bhattacharya \& Sen, 2010; Morsing \& Schultz, 2006; Nielsen \& Thomsen, 2007; Schmeltz, 2012). Searcy and Buslovich (2014) study as stakeholder can appreciate or not a company through sustainability reports by reading if the company's actions are in line with their values and expectations. Bouten et al. (2011) study as sustainability reports should provide stakeholders with information that will allow them to evaluate the companies' social and environmental performance.

Other researches are focused on the reasons that move a growing number of companies in reporting about their CSR commitment by means of sustainability reports, websites and other CSR communication activities (Kolk \& Pinkse, 2010; Perrini, 2005); other papers analyse the effectiveness of CSR disclosure (Castaldo et al., 2009; Weber, 2008).

Therefore, a sizeable part of the literature offers many approaches to the measurement of company disclosed CSR commitments (Bouten et al., 2011; Guthrie \& Abeysekera, 2006; Longo et al., 2005).

Among these works, many studies are focused on the importance of the engagement in order to ensure a good and effectiveness disclosure. Font et al. (2016) suggest four different frameworks to clarify the reasons for CSR engagement, which can explain the shift towards more material CSR practices, and therefore communication:

1. Reputation and risk management theory, based on the avoidance of factors that can have a negative effect on corporate brands (Bebbington et al., 2008); in this sense sustainability reports can renovate a positive image of the firm and realise the importance of 
transparency to reputation (Adams, 2008);

2. Resource-based view of the firm, that suggests that companies act responsibly to maximise their competitive advantage (Russo et al., 1997);

3. Stakeholder Theory, which considers corporations act in response to stakeholder desires, either in a preventive or a proactive way (Wood, 1991); sustainability reporting then becomes a channel to satisfy to the information requirements of different stakeholder groups;

4. Creating Shared Value (CSV) that explains engagement for the purpose of value creation and product distinction. This should join an attitude towards stakeholders and provide success and creation of value (Porter \& Kramer, 2006; Wheeler et al., 2003).

To close with research about CSR disclosure, several studies, are concentrate on the specific instrument of accountability used by companies; in the recent years, these studies consider mainly the integrated report (in particular see de Villiers et al., 2016; Fifka, 2013; FriasAceituno et al., 2013; Frias-Aceituno et al., 2014; Jensen \& Berg, 2012; Lai et al., 2014; Stacchezzini et al., 2016). About this issue, several researches aim to analyse the differences between integrated report (IR) and other standalone report, sustainability report in particular (Mio, 2016; Dey Burns, 2010). The studies analyse, among other things, the targets of IR (Hahn \& Kuhnen, 2013), the focus (IR is concentrated on capitals rather than on stakeholders), the higher degree of customization and the lower degree of comparability of IR, the aims at reporting on outcomes rather than on outputs (Mio, 2016).

Moving towards the specific issue of materiality the researches can be scheduled in different groups. Several researches are focused on materiality definition (Lo, 2010; Iyer \& Whitecotton, 2007; Messier et al., 2005). About definition issue, see also SASB (2013), Account Ability et al. (2006) and GRI (2013). Other researches on materiality stress the importance of the issue (Murillo \& Lozano, 2006; Porter \& Kramer, 2006; Unerman \& Zappettini, 2014).

An important part of the studies is focused on the determinants of materiality and on the materiality indicators. Fasan and Mio (2017) define some determinants of materiality related to legal environment (Webb et al., 2008), to industry (Brammer \& Pavelin, 2006; Cooke, 1992; Patten, 2002; Hassan \& Ibrahim, 2012) and to board characteristics (Frias-Aceituno et al., 2013). Calabrese et al. (2015) focus on different companies' organizational characteristics, such as business models, cultural operating contexts, size and ownership (Adams, 2002; Hahn \& Kuhnen, 2013; Spence, 2007). The authors analyse, in particular, the study by Baumann-Pauly et al. (2013) that presents a 'sustainability reporting gap' related to company size because large companies embrace structured reporting, aiming to improve their image with the general public, while SMEs tend to adopt informal reporting, concentrating their communication efforts on their most important stakeholders, particularly employees (Russo \& Tencati, 2009).

A further area of study related to materiality is focused on the process of materiality analysis and the connected set of expectations and especially the issues that stakeholders consider material and the differences between them and what is considered material by management. This is a crucial and essential element of sustainability and integrated report: a materiality analysis must be implemented in order to achieve the highest level of coincidence between the interests of all stakeholders. The direct involvement of all company stakeholders (stakeholder engagement) could be the way to obtain this result. Font et al. (2016) underline as materiality analysis is the essential process for ranking issues and strategic planning; it allows an integrated approach in defining a sustainability strategy and in reporting itself (Pfitzer et al., 2013). Calabrese et al. (2015) point out that one of the most serious problem with CSR reporting is the lack of completeness in covering all the aspects that are material from a stakeholder perspective (Adams, 2004; Calabrese et al., 2105; de Villiers \& van Staden, 2010; 
O'Dwyer et al., 2005). Companies do not realize a standardized set of stakeholder expectations (Unerman \& Bennett, 2004), and there are no practical tools that offer effective assistance in identifying and analysing the different groups of stakeholders (Boesso \& Kumar, 2009). The process of stakeholder engagement is necessary for understanding the stakeholder expectations and needs and, in this sense, make the companies able to appropriately define the report's content (Calabrese et al., 2105). With a careful and well-planned materiality analysis, the company management is able to detect what are the interests and issues that are dear to company stakeholders and what are the issues that have a significant impact on the company, in addition to those, caused by the company, that have an external impact.

Several studies declare the space of improvement in this area. Calabrese et al. (2015) declare that few studies have investigated into quantitative methods to support materiality assessment in sustainability reporting, and these have not addressed the issues of subjectivity or of completeness in the reporting. Current academic research focuses primarily on measuring CSR activity, rather than assessing the motives behind those activities, measuring their impacts or determining links to stakeholder needs (Basu \& Palazzo, 2008).

Starting from these premises, and in particular from the two fields of study mentioned above (determinants of materiality and process of materiality analysis connected to the expectations of stakeholders), this paper aims to extend the current knowledge on the materiality theme linking these two important research topics. The theoretical pillars of Stakeholder Theory guide us: Theory of Freeman has been an extremely important point for the development of SEAAR (Social and Ethical Accounting, Auditing and Reporting) and the triple bottom-line accounting. In the recent development of accountability and reporting processes we have seen not only a transition from financial to non-financial report but also a changeover from a mono-stakeholder (shareholders) to a multistakeholder model for strategic management (of which reporting is an essential part) (Freeman et al., 2010). Most important international standards and guidelines (e.g. AA1000, GRI Standards, IR Framework) have led this change toward an efficient non-financial disclosure and stress the importance of a full consideration and a real engagement of stakeholders (Boesso et al., 2015; Boesso \& Kumar, 2009; Boesso \& Kumar, 2016; Freeman et al., 2010; Mitchell et al., 2011; Mitchell et al., 1997; Parmar et al., 2010; Thijssens et al., 2015). Jones (1995) has tried to enhance and enrich the Stakeholder Theory of Freeman offering an Instrumental Stakeholder Theory "built on an integration of the stakeholder concept, economic concepts (agency theory, transaction cost economics, and team production theory), insights from behavioral science, and ethics. It focuses on the contracts (relationships) between the firm and its stakeholders and posits that trusting and cooperative relationships help solve problems related to opportunism. Because the costs of opportunism and of preventing or reducing opportunism are significant, firms that contract on the basis of trust and cooperation will have a competitive advantage over those that do not use such criteria" (Jones, 1995, p.432). Relying on the Theory of Jones, focused on the contract (in other words on the relationship) between the company and the stakeholder groups, we would like to deepen and investigate the relationship of cooperation and trust between these two main actors and the possible advantages (for both), and moreover the direct and indirect effects on the disclosure of the companies, in particular on the underlying materiality process. In this sense, we would like to fill the gap about the possible important and crucial effects that stakeholder engagement process could have on the application of materiality principle, on the process of materiality analysis and on the consequent preparation of non-financial report. The need to meet as more as possible the expectations and needs of all the stakeholders is widely studied and investigated; but the process of involment of these stakeholders has not been deeply analysed as a possible essential and decisive aspect in affecting decisions about the materiality processes and the consequences that this principle has on the report itself. 


\section{Empirical research}

Methodology

Aims. Focusing on companies that have drawn up a non-financial report in the period 20132016 and registered it in the official databases of GRI and IIRC, the specific aim of this paper is to analyse the level of the application of materiality (as a core principle in the voluntary accountability process). In particular, we aim to verify its relationship with different types of stakeholders and with their engagement. In other words, we aim to analyse:

- the level of application of the materiality principle (companies that recall the principle in the document) and the spread of materiality matrix;

- the application level of the principle measured through an ordinal categorical variable (MatRelevance: classification of the degree of application of the materiality principle in six hierarchical categories);

- the possible relationship between the application of the materiality principle and the engagement of stakeholders, with a preliminary focus on different industries that are characterized by different types of stakeholder.

Hypotheses. The research hypotheses that will be verified by empirical analysis of the collected data are the following.

\section{Hypothesis 1 - Industry}

There is a relationship between industry and materiality principle's level of application.

A research path has investigated the relationship between voluntary disclosure and industry: these studies have highlighted how public opinion pressure, industry regulation and stakeholder opinion influence the way in which companies disclose their performance (Brammer \& Pavelin, 2006). Other studies have analysed the relationship between voluntary disclosure and being part of an environmentally sensitive industries (Hassan \& Ibrahim, 2012; Patten, 2002) and they have confirmed industry as a key determinant of non-financial disclosure.

\section{Hypothesis 2 - Stakeholder engagement}

There is a relationship between the spread of stakeholder engagement in materiality analysis process and materiality principle's level of application.

Several studies have highlighted the great importance of the involvement of all stakeholders in the production of a voluntary report and in underlying processes (Font et al., 2016; Freeman, 1984; Harrison \& Wicks, 2013; Pfitzer et al., 2013; Wood, 1991). We expect that a wide, more direct as possible, involvement of different categories of stakeholder can have a significant relationship with the achievement of good levels of non-financial information quality and then with high levels of materiality application.

Sample. The sample under analysis is composed by Italian ${ }^{2}$ listed companies that registered their non-financial report (social report, environmental report, sustainability report or integrated report) in the four-year period 2013-2016 in the GRI Sustainability Disclosure

\footnotetext{
${ }^{2}$ We have choosen Italian companies for the wide level of participation of Italian companies in IIRC projects and the high number of companies publishing an integrated report in the last few years. Italy is a pioneer and guide country in this field: it's among the first countries in the world for participation in the IIRC pilot programme (see: http://integratedreporting.org/wp-content/uploads/2013/11/IIRC-Pilot-Programme-BusinessNetwork-backgrounder-October-2013.pdf ). It's also interesting to consider Italian companies because in Italy (up to 2017) there was no law or regulation requiring companies to publish non-financial reports, nor to apply the materiality principle.
} 
Database or in the IIRC Database. This choice has been made to focus the study only on Italian listed companies that have chosen to follow the IIRC and/or GRI guidelines, that foster the application of the materiality principle, and to publish voluntarily their reports on these databases. This represents an extra element to try to select companies that have applied with more depth the materiality analysis and the international guidelines. Consequently, we should have a sufficiently representative sample of Italian companies that apply and follow the principle of materiality in their voluntary disclosure. In our type of analysis would be useless to have and analyse non-financial reports in which (and for which) has not been applied the materiality principle: our focus is on the application level of this principle. For 2013, the number of analysed reports (companies) is 39, 40 for 2014, 37 for 2015 and 35 for 2016. Overall, the empirical analysis has been carried out on a sample of 148 valid observations. All the 148 reports have been subjected to a manual content analysis (carried out individually by the three authors and cross-checked at the end) to detect all the necessary elements for the analysis and to construct the variables of the statistical model.

\section{Variables.}

Dependent variable (Fasan \& Mio, 2017):

- Materiality Relevance (MatRelevance)

Measure of the relevance of materiality through the classification of the application of the principle into six categories:

1) no reference to materiality;

2) the report only states that materiality was a principle followed for the production of the report;

3) the report includes a brief discussion of what is considered to be material;

4) beyond the discussion of what is material, the report communicates the material issues emerging from the analysis;

5) the description of the process and its results are described in a higher degree of detail;

6) the report devotes significant attention to the materiality issue.

The classification has been done by the authors individually and manually for each examined report to achieve a more objective result and to reduce the possible mistakes. According to the content analysis methodology, the ordered categorical variable is the result of the transformation of a qualitative data to a quantitative analysable data (Berelson, 1952). In this sense, we follow a widely used methodology in the field of research on the disclosure quality and, in general, on voluntary disclosure (Wiseman, 1982; Guthrie et al., 2004; Cormier \& Magnan, 2003; Al-Tuwaijri et al., 2004; Aerts \& Cormier, 2009).

\section{Independent variables:}

- Industry (USSIC)

Classification of companies in one of the 10 industrial categories of the US Standard Industrial Classification (SIC). There are seven industrial sectors belonging to the companies analysed: 1) Construction; 2) Publishing; 3) Manufacturing; 4) Transportation, Communications and Energy; 5) Retail and wholesale trade; 6) Finance, Real Estate, Insurance and Holding; 7) Entertainment and recreational services. The industries in which companies operate have been obtained from AIDA database.

$\rightarrow$ Environmental sensible industry (ESI)

Membership to one of seven ESI. Cho \& Patten (2007) identify as ESI the following industries (based on the first two numbers of the US SIC classification): 10 (mining), 13 (oil exploration), 26 (paper), 28 (chemical and allied products) 29 (petroleum refining), 33 (metals), 49 (utilities). This is a dichotomous variable: "0" for no 
membership to one of ESI and "1" for the membership to one of ESI.

- Stakeholder engagement (StakeEngage)

Stakeholder engagement level in the materiality analysis process measured through the extent and the type of events or engagement actions analysed through careful reading of the reports, especially sections on the process of materiality analysis and the relationship with the stakeholders. This is an ordered categorical variable that classifies stakeholder engagement in the materiality analysis process in three categories:

1) a statement of no involvement or lack of statements about it;

2) indirect and / or partial engagement of reference stakeholders through remote activities such as surveys, questionnaires, interviews and individual talk, analysis of generic information gathered by external companies, analysis of complaints / suggestions, analysis of the press review;

3) direct and/or wide involvement of stakeholders through direct and participative activities such as focus groups, dedicated events, meetings and workshops.

\section{Control variables}

In addition to the two traditional and essential control variables of income (measured by ROA) and company size (measured by Total Assets), and to be sure to capture and isolate the main aspects that could affect the materiality level of application (i.e. the materiality analysis), we have selected and insert the following four aspects in the creation process of non-financial reports:

- Experience in voluntary disclosure (Experience)

Number of years since the company began publishing non-financial reports. The data has been collected from the introduction of the reports and / or through the report archives of the companies' websites.

- Review of the report (Assurance)

Presence of a certificate assurance process. This is a dichotomous variable: " 0 " for the absence of an assurance and " 1 " for the presence of assurance by a certified entity that has issued a compliant certificate. The data was obtained from the analysis of the individual reports where it is always stated whether the assurance is present or not and in which the auditors' report is attached.

- GRI principles (GRIlevel)

This is an ordered categorical variable that classifies the level of application of the GRI reporting principles (version 3 and 4) in three categories: 1) absence of application level declaration or application level $\mathrm{C}$ in version $3 ; 2$ ) application level $\mathrm{B}$ in version 3 and "accordance-core" in version 4; 3) application level A in version 3 and "comprehensive" in version 4. The data on the level of application of the principle has been collected analysing single reports, in particular the paragraph on the Methodology at the beginning or at the bottom of the report.

- IIRC principles and Integrated Report (IIRC)

This is an ordered categorical variable that classifies the level of application of the IIRC reporting principles and the publication of an integrated report (within the International IR Framework) in four categories: 1) absence of any references to the integrated report and the IIRC; 2) a stated goal of shortly producing a first integrated report and/or partial application of the principles of the International IR Framework; 3) presence of an "integrated report" but coexisting with a traditional non-financial report (sustainability, social, environmental); 4) presence of an integrated report in accordance with the IIRC principles. The data on the level of application of the principle has been collected analysing single reports, in particular the paragraph on the Methodology at the beginning 
or at the bottom of the report.

\section{Results}

From the first part of the analysis carried out on collected data, it has turned out (Table 1) that in $89 \%$ of the 148 total observations the materiality principle has been applied. A graphical representation of the outcome of the materiality analysis process (materiality matrix) has been used in fewer cases, the $73 \%$ of the total. In several observed cases, the report is prepared considering the materiality and results obtained from the underlying internal process but the whole is not graphically formalized by a suitable matrix.

Table 1. Frequencies of Materiality and Materiality Matrix

Table 2. Frequencies over years

Table 3. Frequencies Statistics of dependent variable over years

Subdividing the sample between years (Table 2), we can observe the evolution in the last four years: there is a strong trend, with a significant peak in 2015, towards the application of materiality in social-environmental reports. In 2015, only one company in the sample has not applied the principle, unlike the previous two years where at least six companies have drafted the reports without considering the principle. The same strong trend is evident for the use of the materiality matrix in the report: only four companies in 2015 have not used it, a fifth compared to 2013. The data analysis of the dependent variable (Table 3) confirms this increasingly widespread application: the average of the materiality level measured by MatRelevance variable is constantly growing. Table 4 shows the main descriptive statistics of all variables included in the analysis.

Table 4. Frequencies Statistics of variables used

According to the correlation matrix (Table 5) we underline the strong positive (and significant) correlation of the StakeholderEngagement variable with the dependent variable.

Table 5. Nonparametric Correlation Matrix (Spearman's rho)

To test the first hypothesis of this research, we have started defining the basic linear model which will be subjected to a statistical analysis (OLS regression) where materiality is determined only by the two essential and consolidated control variables, income (measured by ROA) and company size (measured by Total Assets):

MaterialityRelevance $=\alpha+\beta 1$ TotalAssets $+\beta 2$ ROA $+\varepsilon$

After performing a regression analysis on this model, we have inserted the independent variable "Industry" (as a fixed effect) and done again the regression analysis with the following updated model:

MaterialityRelevance $=\alpha+\beta 1$ TotalAssets $+\beta 2$ ROA $+\beta 3$ Industry $+\varepsilon$

Table 6. OLS Regression with and without Industry variable

The results of the two regression analyses (Table 6) show how the basic model has a low R2 (0.026) and no significance. Adding the "Industry" variable, the model has a higher R2 (0.092) and above all a good significance with the MatRelevance variable. 
This first analysis confirms Hypothesis 1: industry has a key role on the level of application of the materiality principle. To confirm this first result, we have done an analysis of the differences between the mean values of the dependent variable in the seven industrial sectors and the averages in the rest of the sample. These differences have been subjected to a t-test (Table 7) where the null hypothesis is that the mean values of the dependent variable in the seven industrial sectors are equal to the averages of the same values in the rest of the sample.

Table 7. Two-group mean-comparison test: Materiality in different industries

The analysis confirms that companies in the Construction industry (1) disclose non-financial reports with a higher level of materiality: they have obtained a MaterialityRelevance rating close to 5 (of the original, not transformed, scale of value) as opposed to the rest of the industries that don't fully reach value 4 . The difference is significant at $10 \%$ level. The difference in industry of Entertainment and recreational services (7) is significant at 5\% level: companies in this industry have a higher level of application of the materiality compared to the rest of the industries, they get the value of 6 for MatRelevance unlike the rest of the industries that have a value of 4 .

The first result is in line with Brammer \& Pavelin's study (2006), which argues that companies operating in in pharmaceutical, chemical and construction industries are more likely to carry out voluntary disclosure.

For completeness, we have done an analysis of the differences between the mean value of the dependent variable in the environmentally sensitive industries (ESI) and the average in the rest of the sample. In our sample only industry 49 (utilities) is represented in the group of ESI, with a total of 40 reports. The differences have been subjected to a t-test (Table 8) where the null hypothesis is that the mean value of the dependent variable in the ESI are equal to the average of the same value in the rest of the sample.

Table 8. Two-group mean-comparison test: Materiality in ESI

There are no significant differences (at 95\% confidence level) between the values of the dependent variable in the reports of companies operating in the ESI and the values in the reports of the rest of the companies.

Proceeding in the verification of the research hypotheses (second Hypothesis), we have expanded the model with the addition of all the control variables and the independent variables. The complete model is the follow:

MaterialityRelevance $=\alpha+\beta 1$ TotalAssets $+\beta 2$ ROA $+\beta 3$ Experience $+\beta 4$ Assurance $+\beta 5$ GRIlevel $+\beta 6$ IIRC $+\beta 7$ StakeEngage $+\beta 8$ ESI $+\varepsilon$

Table 9. Ordinary Least Squares (OLS) Regression

Table 9 shows the results of the regression analysis that has been performed to determine the possible relationship between the independent variables abd the dependent variable. The OLS regression is significant at $1 \%$ level and has an Adjusted R-squared of 0.32 . StakeholderEngagement variable has a significant and positive relationship (at $1 \%$ level): this result confirms Hypothesis 2, where stakeholder engagement has an important role to define and increase the materiality level. There is also a significant and negative relationship (at $10 \%$ level) with ESI independent variable: it's a further confirmation of Hypothesis 1, according to which Industry has a fundamental relationship with voluntary disclosure and materiality 
principle's level of application.

We have checked all the necessary assumptions and the possible obstacles to correctly run an OLS regression: linear relationship, normality, auto-correlation, multicollinearity, homoscedasticity. We have also treated all scale values with a logarithmic transformation and the dependent variable with a Box-Cox transformation (using the square of values) to reach a normal distribution of values. As a further confirmation of the obtained results we have runned an OLS regression separately for each year under investigation and the results are the same.

\section{Discussion}

The results of the analyses confirm firstly how industry plays a key role in decisions regarding the quantity and quality of non-financial disclosure of a company. According to previous studies on the subject (Cooke, 1992; Hassan \& Ibrahim, 2012; Patten, 2002), industry influences significantly board of the company on decisions about the type of disclosure to be published and about the application (or non-application) of the materiality principle (but also about its level of application and deepening). Direct and indirect external pressures, social-environmental impact of the core business, stakeholder expectations, behaviour of the competing companies have a crucial role on management choices regarding voluntary disclosure and the underline process. In detail, the analysis has shown that even in the case of Italian listed companies that publish sustainability and integrated reports, construction companies have a greater propensity to voluntary disclosure and, in the case of our study, to a significant application of the principle of materiality. We may suppose that this trend is due to the type of activity that has, though with a lower level than, for example, the energy and extractive sector, a relevant and tangible environmental impact and therefore subjected to the attention and pressure from different stakeholder categories, from local public administrations to citizens in the area concerned by industrial activity. This attention is often very high also for the issue of corruption: a very strong and current problem of this industry. In entertainment and recreational services industry, the results of the empirical analysis have suggested that companies in this industry tend to apply more in depth the principle of materiality and the underlying process in their non-financial reports. The direct and tangible impact on population and the need, for these companies, to find more and more trust and to create a strong link with customers first but also with all the stakeholders push companies to a greater transparency and to better meet the information needs of all categories of stakeholders. The ESI variable analysis has underline this key role of industry but the type of relationship (negative) with materiality principle level of application is in contrast with the previous studies on ESI and voluntary disclosures: Hassan \& Ibrahim (2012) and Patten (2002) have found a significant and positive relationship between belonging to one of these industries and tendency to voluntary disclosure. We have found that ESI companies tend to apply less thoroughly the principle of materiality. Maybe the contrast is due to the presence in our sample of only one industry of the seven ESI, although the industry in our sample is the utilities one, that is well representative, and characterize, in our sample, by 40 reports; or in that their study isn't focused on materiality.

As confirmation of the second research hypothesis, the results of our empirical analysis have found that stakeholder engagement level is strongly related, with a positive relationship, to the level of implementation of the materiality principle. This result also points out and confirms, even from a quantitative point of view, an important aspect and adds a significant argumentation to the literature about voluntary disclosure and materiality principle. Implementing a solid and extensive stakeholder engagement process is a necessary condition, but not an enough condition, in order to reach a significant degree of application of the 
principle of materiality. This strong relationship is not obvious: many companies have active materiality analysis processes without planning any type of stakeholder engagement, although most of them report in their voluntary disclosure documents that they have consider the needs and issues deemed important by reference stakeholders (often through interaction with companies specialized in public opinion analysis or analysing the press review or simply getting the management's opinion on it). A strong push to this process of engagement comes and can be achieved even more by the standard setter of non-financial reports (primarily IIRC and GRI). The new IIRC directives and the GRI Sustainability Reporting Standards (2016) give greater emphasis to stakeholder engagement and the process behind. On the other hand, an increasingly widespread and broad stakeholder engagement by the companies may influence and push, over time, the same standard setter to implement even more this important aspect in reporting principles.

Finally, the results of this paper show how in the last four years, in Italy, the application of the principle of materiality and the use of the appropriate matrix (although not all companies applying materiality then use a matrix in the report) are steadily increasing. The GRI Sustainability Reporting Standards and the latest IIRC directives are becoming more and more tending to an important application of the principle as well as the proper implementation of a valid underlying process. An update of this work or other studies on the subject will be able to confirm this trend in the coming years and analyse its evolution over time.

\section{Conclusion}

The paper is focused on materiality principle application in voluntary disclosure of Italian listed companies in the period 2013-2016. After an analysis of the spread of the principle application and its materiality matrix, the study has continued testing statistically the existence of a relationship between the application level of the principle and the process of stakeholder engagement, controlling for some variables that could have an impact on the dependent variable.

The quantitative analysis has shown that stakeholder engagement (and the indirect related variable of industry) play a fundamental part in the report production process, particularly in the materiality analysis itself.

By joining to the Stakeholder Theory and Instrumental Stakeholder Theory and starting from the latest international studies on these issues, this study extends and enriches the research paths on CSR, voluntary disclosure and materiality analysis in non-financial reports, confirming the industry as an important aspect and adding stakeholder engagement as an essential and decisive aspect. The importance and effect of stakeholder engagement affect the decisions about the materiality and the consequences that this principle has on the report itself. This research has highlighted that without a large and mostly direct stakeholder engagement, companies are not able, in most cases, to reach high levels of implementation of the materiality principle; therefore, these companies cannot have a proper and well-targeted communication. Without the widest stakeholder engagement, company is unable to implement a process that takes into account all aspects relevant for the stakeholders themselves and therefore cannot talk with mutual satisfaction with them: this is the conclusion that comes from reading the results of this empirical analysis.

This research has a direct and immediate utility as well as for international bodies that are defining standards and guidelines on non-financial reports by defining high levels of stakeholder engagement as one of the principal goals, also for companies that choose to produce voluntary reports. A further important motivation that comes from these findings is for stakeholder groups who are struggling to be heard and involved in the decision-making and information processes of companies to which they are linked. Their request is founded 
and should be taken seriously by the management; without their real engagement, is missing a fundamental element in the processes of transparency and disclosure.

At the end of the study, we have to focus on limits of our research:

1) this paper analyses companies of only one country (Italy); the results may therefore reflect the characteristics of the country and the influence that is directly and indirectly exerted by legislation and customs of resident companies. However, it is important to point out that most of the companies of the sample, even if based in Italy, have a broad international breath, operating in different countries around the world and having affiliates in many countries. Even though the headquarter is in Italy, pressures by different stakeholder groups and public opinion in different countries could partially resolve the problem of the single country;

2) this paper analyses only four years (2013-2016), although, in the years prior to 2013, the number of reports with the required characteristics decrease significantly.

We think that future further researches will confirm the results of this study in primis broadening the analysed countries and in secundis expanding the analysed time period. It would be useful also to analyse reports that, although not officially registered on the GRI and IIRC network, have implemented these international standards at different levels. We emphasize the importance of new research to focus on the internal dynamics of the implementation of materiality analysis, on the underlying processes, and in particular on the effects of stakeholder engagement on these companies' processes. Particularly useful and interesting would be to research and define a stakeholder engagement process able to achieve the just detailed results and how this could be implemented in companies' dynamics. 


\section{References}

AccountAbility, BT Group, Lloyds Register Quality Assurance (LRQA) (2006). The Materiality Report - Aligning Strategy, Performance and Reporting.

Adams, C. A. (2002). Internal organisational factors influencing corporate social and ethical reporting. Beyond current theorizing. Accounting, Auditing and Accountability Journal, 15(2), 223-250.

Adams, C. A. (2004). The ethical, social and environmental reporting - Performance portrayal gap. Accounting, Auditing and Accountability Journal, 17(5), 731-757.

Adams, C. A. (2008). A commentary on: corporate social responsibility reporting and reputation risk management. Accounting, Auditing \& Accountability Journal, 21(3), 365370.

Aerts, W., \& Cormier, D. (2009). Media legitimacy and corporate environmental communication. Accounting, Organizations \& Society, 34(1), 1-27.

Al-Tuwaijri, S. A., Christensen, T. E., \& Hughes II, K. E. (2004). The relations among environmental disclosure, environmental performance, and economic performance: a simultaneous equations approach. Accounting, Organizations \& Society, 29(5/6), 447.

Basu, K., \& Palazzo, G. (2008). Corporate Social Responsibility: a process model of sensemaking. Academy of Management Review, 33(1), 122-136.

Baumann-Pauly, D., Wickert, C., J. Spence, L., \& Scherer, A. G. (2013). Organizing Corporate Social Responsibility in Small and Large Firms: Size Matters. Journal of Business Ethics, 115(4), 693-705.

Bebbington, J., Larrinaga, C., \& Moneva, J. M. (2008). Corporate social reporting and reputation risk management. Accounting, Auditing \& Accountability Journal, 21, 337-361.

Berelson, B. (1952). Content analysis in communication research. Free Press.

Boesso, G., Favotto, F., \& Michelon, G. (2015). Stakeholder Prioritization, Strategic Corporate Social Responsibility and Company Performance: Further Evidence. Corporate Social Responsibility \& Environmental Management, 22(6), 424-440.

Boesso, G., \& Kumar, K. (2009). Stakeholder prioritization and reporting: Evidence from Italy and the US. Accounting Forum, 33(2), 162-175.

Boesso, G., \& Kumar, K. (2016). Examining the association between stakeholder culture, stakeholder salience and Stakeholder Engagement activities. Management Decision, 54(4), 815-831.

Bouten, L., Everaert, P., Van Liedekerke, L., De Moor, L., \& Christiaens, J. (2011). Corporate social responsibility reporting: A comprehensive picture? Accounting Forum, 35(3), 187-204.

Brammer, S., \& Pavelin, S. (2006). Voluntary Environmental Disclosures by Large UK Companies. Journal of Business Finance \& Accounting, 33(7/8), 1168-1188.

Calabrese, A., Costa, R., \& Rosati, F. (2015). A feedback-based model for CSR assessment and materiality analysis. Accounting Forum, 39(4), 312-327.

Castaldo, S., Perrini, F., Misani, N., \& Tencati, A. (2009). The missing link between corporate social responsibility and consumer trust: The case of fair trade products. Journal of business ethics, 84(1), 1-15.

Cho, C. H., \& Patten, D. M. (2007). The role of environmental disclosures as tools of legitimacy: A research note. Accounting, Organizations \& Society, 32(7/8), 639-647.

Cooke, T. E. (1992). The Impact of Size, Stock Market Listing and Industry Type on Disclosure in the Annual Reports of Japanese Listed Corporations. Accounting \& Business Research (Wolters Kluwer UK), 22(87), 229-237.

Cormier, D., \& Magnan, M. (2003). Environmental reporting management: a continental European perspective. Journal of Accounting \& Public Policy, 22(1), 43-62. 
de Villiers, C., Venter, E. R., \& Hsiao, P. C. K. (2016). Integrated reporting: background, measurement issues, approaches and an agenda for future research. Accounting \& Finance.

Deegan, \& Rankin. (1997). The materiality of environmental information to users of annual reports. Accounting, Auditing \& Accountability Journal, 10(4), 562-583.

Dey, C., \& Burns, J. (2010). Integrated reporting at Novo Nordisk. In A. Hopwood, J. Unerman, \& J. Fries (Eds.), Accounting for sustainability: Practical insights, 215-232.

Du, S., Bhattacharya, C. B., \& Sen, S. (2010). Maximizing business returns to corporate social responsibility (CSR): The role of CSR communication. International Journal of Management Reviews, 12(1), 8-19.

Eccles, R. G., \& Krzus, M. P. (2014). The Integrated Reporting Movement: Meaning, Momentum, Motives, and Materiality. John Wiley \& Sons.

Fasan, M., \& Mio, C. (2017). Fostering Stakeholder Engagement: The Role of Materiality Disclosure in Integrated Reporting. Business Strategy and the Environment, 26(3), 288305.

Fifka, M. S. (2013). Corporate responsibility reporting and its determinants in comparative perspective. A review of the empirical literature and a meta-analysis. Business Strategy and the Environment, 22(1), 1-35.

Font, X., Guix, M., \& Bonilla-Priego, M. J. (2016). Corporate social responsibility in cruising: Using materiality analysis to create shared value. Tourism Management, 53, 175186.

Freeman, R. E. (1984). Strategic management: A stakeholder approach (Vol. 1). Pitman.

Freeman, R. E., Harrison, J. S., Wicks, A. C., Parmar, B., \& de Colle, S. (2010). Stakeholder Theory: The State of the Art. Cambridge and New York.

Frias-Aceituno, J. V., Rodriguez-Ariza, L., \& Garcia-Sanchez, I. (2013). The Role of the Board in the Dissemination of Integrated Corporate Social Reporting. Corporate Social Responsibility \& Environmental Management, 20(4), 219-233.

Frias-Aceituno, J. V., Rodríguez-Ariza, L., \& Garcia-Sánchez, I. M. (2013). Is integrated reporting determined by a country's legal system? An exploratory study. Journal of Cleaner Production, 44, 45-55.

Frias-Aceituno, J. V., Rodríguez-Ariza, L., \& Garcia-Sánchez, I. M. (2014). Explanatory Factors of Integrated Sustainability and Financial Reporting. Business Strategy \& the Environment, 23(1), 56-72.

Global Reporting Initiative (GRI) (2013). G4 Sustainability Reporting Guidelines - Reporting Principles and Standard Disclosures.

Global Reporting Initiative (GRI) (2013). G4 Sustainability Reporting Guidelines Implementation Manual.

Global Sustainability Standards Board (GSSB) (2016). Consolidated Set of GRI Sustainability Reporting Standards

Gray, R., Owen, D., \& Maunders, K. (1987). Corporate Social Reporting: Accounting and Accountability. Prentice-Hall.

Gray, R., Dey, C., Owen, D., Evans, R., \& Zadek, S. (1997). Struggling with the praxis of social accounting: Stakeholders, accountability, audits and procedures. Accounting, Auditing \& Accountability Journal, 10(3), 325-364.

Guthrie, Petty, Yongvanich, \& Ricceri. (2004). Using content analysis as a research method to inquire into intellectual capital reporting. Journal of Intellectual Capital, 5(2), 282-293.

Guthrie, J., \& Abeysekera, I. (2006). Content analysis of social, environmental reporting: what is new? Journal of Human Resource Costing \& Accounting, 10, 114-126.

Hahn, R., \& Kühnen, M. (2013). Determinants of sustainability reporting: a review of results, trends, theory, and opportunities in an expanding field of research. Journal of Cleaner Production, 59, 5-21. 
Harrison, J. S., \& Wicks, A. C. (2013). Stakeholder theory, value, and firm performance. Business ethics quarterly, 23(1), 97-124.

Hassan, A., \& Ibrahim, E. (2012). Corporate Environmental Information Disclosure: Factors Influencing Companies' Success in Attaining Environmental Awards. Corporate Social Responsibility \& Environmental Management, 19(1), 32-46.

Holstrum, G. L., \& Messier Jr., W. F. (1982). A Review and Integration of Empirical Research on Materiality. Auditing: A Journal of Practice \& Theory, 2(1), 45.

International Integrated Reporting Council (IIRC), \& International Federation of Accountants (IFAC) (2015). Materiality in IR - Guidance for the preparation of integrated reports.

Iyer, G., \& Whitecotton, S. (2007). Re-defining "materiality": an exercise to restore ethical financial reporting. Advances in Accounting, 23, 49-83.

Jensen, J. C., \& Berg, N. (2012). Determinants of traditional sustainability reporting versus integrated reporting. An institutionalist approach. Business Strategy and the Environment, 21(5), 299-316.

Jones, P., Comfort, D., \& Hillier, D. (2016). Materiality in corporate sustainability reporting within UK retailing. Journal of Public Affairs (14723891), 16(1), 81-90.

Jones, T. M. (1995). Instrumental Stakeholder Theory: A Synthesis of Ethics and Economics. The Academy of Management Review, 20(2), 404-437.

Kolk, A., \& Pinkse, J. (2010). The integration of corporate governance in corporate social responsibility disclosures. Corporate Social Responsibility and Environmental Management, 17(1), 15-26.

Kolk, A., \& Perego, P. (2010). Determinants of the adoption of sustainability assurance statements: an international investigation. Business Strategy \& the Environment, 19(3), 182-198.

Lai, A., Melloni, G., \& Stachezzini, R. (2014). Corporate sustainable development: is "integrated reporting" a legitimation strategy? Business Strategy and the Environment.

Lo, K. (2010). Materiality and voluntary disclosures. Journal of Accounting and Economics, 49(1), 133-135.

Longo, M., Mura, M., \& Bonoli, A. (2005). Corporate social responsibility and corporate performance: The case of Italian SMEs. Corporate Governance, The International Journal of business in Society, 5(4), 28-42.

Messier, J., William F., Martinov-Bennie, N., \& Eilifsen, A. (2005). A Review and Integration of Empirical Research on Materiality: Two Decades Later. Auditing: A Journal of Practice \& Theory, 24(2), 153-187.

Mio, C. (a cura di) (2016). La rendicontazione sociale negli atenei italiani: valori, modelli, misurazioni. Franco Angeli.

Mitchell, R. K., Agle, B. R., Chrisman, J. J., \& Spence, L. J. (2011). Toward a Theory of Stakeholder Salience in Family Firms. Business Ethics Quarterly, 21(2), 235-255.

Mitchell, R. K., Agle, B. R., \& Wood, D. J. (1997). Toward a Theory of Stakeholder Identification and Salience: Defining the Principle of Who and What Really Counts. Academy of Management Review, 22(4), 853-886.

Mock, T. J., Strohm, C., \& Swartz, K. M. (2007). An Examination of Worldwide Assured Sustainability Reporting. Australian Accounting Review, 17(41), 67-77.

Morsing, M., \& Schultz, M. (2006). Corporate social responsibility communication: stakeholder information, response and involvement strategies. Business Ethics: A European Review, 15(4), 323-338.

Murillo, D., \& Lozano, J. M. (2006). SMEs and CSR: An approach to CSR in their own words. Journal of Business Ethics, 67, 227-240.

Nielsen, A. E., \& Thomsen, C. (2007). Reporting CSR: What and how to say it? Corporate Communications, 12(1), 25-40. 
O'Dwyer, B., Unerman, J., \& Hession, E. (2005). User needs in sustainability reporting: perspective of stakeholders in Ireland. European Accounting Review, 14(4), 759-787.

Parmar, B. L., Freeman, R. E., Harrison, J. S., Wicks, A. C., Purnell, L., \& de Colle, S. (2010). Stakeholder Theory: The State of the Art. Academy of Management Annals, 4(1), 403-445.

Patten, D. M. (2002). The relation between environmental performance and environmental disclosure: a research note. Accounting, Organizations \& Society, 27(8), 763-773.

Perrini, F. (2005). Building a European portrait of corporate social responsibility reporting. European management journal, 23(6), 611-627.

Pfitzer, M., Bockstette, V., \& Stamp, M. (2013). Innovating for shared value. Companies that deliver both social benefits and business value rely on five mutually reinforcing elements. Harvard Business Review, 100-107.

Porter, M. E., \& Kramer, M. R. (2006). Strategy \& Society: The Link Between Competitive Advantage and Corporate Social Responsibility. Harvard Business Review, 84(12), 78-92.

Russo, M. V., \& Fouts, P. A. (1997). A Resource-Based Perspective on Corporate Environmental Performance and Profitability. The Academy of Management Journal, 40(3), 534-559.

Russo, A., \& Tencati, A. (2009). Formal vs. informal CSR strategies: Evidence from Italian micro, small, medium-sized, and large firms. Journal of Business Ethics, 85, 339-353.

Schmeltz, L. (2012). Consumer-oriented CSR communication: focusing on ability or morality? Corporate Communications: An International Journal, 17(1), 29-49.

Searcy, C., \& Buslovich, R. (2014). Corporate perspectives on the development and use of sustainability reports. Journal of Business Ethics, 121(2), 149-169.

Sierra-García, L., Zorio-Grima, A., \& García-Benau, M. A. (2013). Stakeholder Engagement, Corporate Social Responsibility and Integrated Reporting: An Exploratory Study. Corporate Social Responsibility \& Environmental Management, 22(5), 286-304.

Spence, L. J. (2007). CSR and small business in a European policy context: the five "C" s of CSR and small business research agenda 2007. Business and society review, 112(4), 533552.

Stacchezzini, R., Melloni, G., \& Lai, A. (2016). Sustainability management and reporting: the role of integrated reporting for communicating corporate sustainability management. Journal of Cleaner Production, 136, 102-110.

Sustainability Accounting Standard Board (2013). Conceptual Framework.

Thijssens, T., Bollen, L., \& Hassink, H. (2015). Secondary Stakeholder Influence on CSR Disclosure: An Application of Stakeholder Salience Theory. Journal of Business Ethics, 132(4), 873-891.

Unerman, J., \& Bennett, M. (2004). Increased stakeholder dialogue and the internet: towards greater corporate accountability or reinforcing capitalist hegemony? Accounting, Organizations and Society, 29(7), 685-707.

Unerman, J., \& Zappettini, F. (2014). Incorporating Materiality Considerations into Analyses of Absence from Sustainability Reporting. Social and Environmental Accountability Journal, 34(3), 172-186.

Vance, D. E. (2011). A Meta-analysis of Empirical Materiality Studies. Journal of Applied Business Research, 27(5), 53-72.

Vaz, N., Fernandez-Feijoo, B., \& Ruiz, S. (2016). Integrated reporting: an international overview. Business Ethics: A European Review, 25(4), 577-591.

Webb, K. A., Cahan, S. F., \& Sun, J. (2008). The effect of globalization and legal environment on voluntary disclosure. The International Journal of Accounting, 43(3), 219245 . 
Weber, M. (2008). The business case for corporate social responsibility: A company-level measurement approach for CSR. European Management Journal, 26(4), 247-261.

Wheeler, D., Colbert, B., \& Freeman, R. E. (2003). Focusing on value: Reconciling corporate social responsibility, sustainability and a stakeholder approach in a network world. Journal of general management, 28(3), 1-28.

Wiseman, J. (1982). An Evaluation of Environmental Disclosures Made in Corporate Annual Reports. Accounting, Organizations \& Society, 7(1), 53-63.

Wood, D. J. (1991). Corporate social performance revisited. Academy of management review, 16(4), 691-718. 


\section{Tables}

Table 1. Frequencies of Materiality and Materiality Matrix

\begin{tabular}{lcccc}
\hline & \multicolumn{2}{c}{ Materiality } & \multicolumn{2}{c}{ Materiality Matrix } \\
\hline No & Frequency & Percent & Frequency & Percent \\
Yes & 16 & 11 & 40 & 27 \\
Total & 132 & 89 & 108 & 73 \\
\hline
\end{tabular}

Table 2. Frequencies over years

\begin{tabular}{lcccccccc}
\hline & \multicolumn{4}{c}{ Materiality } & \multicolumn{5}{c}{ Materiality Matrix } \\
\hline No & 2013 & 2014 & 2015 & 2016 & 2013 & 2014 & 2015 & 2016 \\
Yes & 6 & 10 & 1 & 1 & 21 & 13 & 4 & 4 \\
Total & 33 & 30 & $36^{\star \star \star}$ & 34 & 18 & $27^{\star}$ & $33^{\star *}$ & 31 \\
\hline
\end{tabular}

Significance of the difference with the previous year:

$* \mathrm{p}<0.10$

$* * \mathrm{p}<0.05$

$* * * \mathrm{p}<0.01$

Table 3. Frequencies Statistics of dependent variable over years

\begin{tabular}{lcccc}
\hline \multicolumn{4}{c}{ MatRelevance } \\
\hline $\mathrm{N}$ & 2013 & 2014 & 2015 & 2016 \\
Mean & 38 & 39 & 36 & 35 \\
Median & 3.395 & 3.846 & 4.250 & 4.458 \\
Minimum & 3.000 & 4.000 & 4.000 & 4.000 \\
Maximum & 1.000 & 1.000 & 1.000 & 1.000 \\
\hline
\end{tabular}

Table 4. Frequencies Statistics of variables used

\begin{tabular}{lccccccccc}
\hline & MatRelevance & TotalAssets & \multicolumn{1}{c}{ ROA } & \multicolumn{2}{c}{ Experience Assurance GRIlevel } & IIRC & StakeEngage & ESI \\
\hline Mean & 3.972 & 42640954 & 0.007 & 10.507 & 0.824 & 2.236 & 1.520 & 1.730 & 0.270 \\
Median & 4.000 & 7195085 & 0.000 & 11.000 & 1.000 & 2.000 & 1.000 & 2.000 & 0.000 \\
Std.Dev. & 1.694 & 93444276 & 0.037 & 5.253 & 0.381 & 0.632 & 0.951 & 0.743 & 0.446 \\
Minimum & 0.000 & 146671 & -0.110 & 1.000 & 0.000 & 1.000 & 1.000 & 1.000 & 0.000 \\
Maximum & 6.000 & 447692494 & 0.150 & 24.000 & 1.000 & 3.000 & 4.000 & 3.000 & 1.000 \\
$\mathrm{~N}$ & 148 & 148 & 148 & 148 & 148 & 148 & 148 & 148 & 148 \\
\hline
\end{tabular}


$\underline{\text { Table 5. Nonparametric Correlation Matrix (Spearman's rho) }}$

\begin{tabular}{|c|c|c|c|c|c|c|c|c|c|}
\hline & $\begin{array}{c}\text { Mat } \\
\text { Relevance }\end{array}$ & $\begin{array}{c}\text { Total } \\
\text { Assets }\end{array}$ & ROA & xperience & Assurance & $\begin{array}{l}\text { GRI } \\
\text { level }\end{array}$ & IIRC & $\begin{array}{c}\text { Stake } \\
\text { Engage }\end{array}$ & $\mathrm{ESI}$ \\
\hline MatRelevance & 1 & & & & & & & & \\
\hline TotalAssets & 0.071 & 1 & & & & & & & \\
\hline $\mathrm{ROA}$ & -0.040 & $0.161^{*}$ & 1 & & & & & & \\
\hline Experience & 0.036 & $0.500^{* * *}$ & 0.042 & 1 & & & & & \\
\hline Assurance & $0.232^{\star * *}$ & -0.014 & $-0.308^{* * *}$ & 0.122 & 1 & & & & \\
\hline GRllevel & $0.168^{* *}$ & 0.071 & -0.075 & 0.020 & $0.475^{\star \star \star}$ & 1 & & & \\
\hline IIRC & $0.159^{*}$ & $0.293^{\star * *}$ & 0.080 & $0.177^{\star *}$ & $0.205^{\star *}$ & 0.003 & 1 & & \\
\hline StakeEngage & $0.584^{* * *}$ & $-0.088^{*}$ & -0.121 & $0.141^{*}$ & $0.242^{* * *}$ & $0.180^{* *}$ & $0.183^{* *}$ & 1 & \\
\hline ESI & -0.039 & 0.128 & $-0.162^{\star *}$ & 0.088 & $0.241^{* * *}$ & $0.327^{* \star *}$ & $0.154^{*}$ & 0.043 & 1 \\
\hline
\end{tabular}

Table 6. OLS Regression with and without Industry variable

\begin{tabular}{lcc}
\hline & $\begin{array}{c}\text { OLS } \\
\text { (MatRelevance) }\end{array}$ & $\begin{array}{c}\text { OLS } \\
\text { (MatRelevance) }\end{array}$ \\
\hline TotalAssets & $0.725(0.523)$ & $2.134^{* * *}(0.750)$ \\
ROA & $-31.625(28.851)$ & $-11.506(31.200)$ \\
Industry & No & Yes \\
Intercept & $10.219(8.732)$ & $-10.738(11.770)$ \\
Observation & 148 & 148 \\
$\mathrm{~F}$ & 1.780 & $2.35^{\star *}$ \\
Adj. R2 & 0.026 & 0.092 \\
$* \mathrm{p}<0.10$ & & \\
$* * \mathrm{p}<0.05$ & & \\
$* * * \mathrm{p}<0.01$ & &
\end{tabular}

Table 7. Two-group mean-comparison test: Materiality in different industries

\begin{tabular}{|c|c|c|c|c|}
\hline \multirow[b]{2}{*}{ Industry } & \multicolumn{4}{|c|}{ MatRelevance } \\
\hline & $\begin{array}{l}\text { Industry } \\
\text { mean }\end{array}$ & $\begin{array}{c}\text { Rest of } \\
\text { sample } \\
\text { mean }\end{array}$ & Difference & T-test \\
\hline Construction & 26.000 & 18.214 & -7.786 & $-1.675^{\star}$ \\
\hline Publishing & 15.600 & 18.741 & 3.141 & 0.535 \\
\hline Manufacturing & 18.782 & 18.608 & -0.175 & -0.060 \\
\hline Transportation, Communications and Energy & 18.653 & 18.626 & -0.027 & -0.012 \\
\hline Retail and wholesale trade & 15.909 & 18.854 & 2.945 & 0.729 \\
\hline Finance, Real Estate, Insurance and Holding & 17.042 & 19.400 & 2.358 & 1.044 \\
\hline Entertainment and recreational services & 33.250 & 18.230 & -15.021 & $-2.338^{* *}$ \\
\hline $\begin{array}{l}\mathrm{p}<0.10 \\
* * \mathrm{p}<0.05 \\
* * \mathrm{p}<0.01\end{array}$ & & & & \\
\hline
\end{tabular}


Table 8. Two-group mean-comparison test: Materiality in ESI MatRelevance

\begin{tabular}{cccc}
\hline ESI mean & Rest of sample mean & Difference & T-test \\
\hline 17.550 & 19.037 & 1.487 & 0.623 \\
\hline$* \mathrm{p}<0.10$ & & & \\
$* * \mathrm{p}<0.05$ & & & \\
$* * * \mathrm{p}<0.01$ & & &
\end{tabular}

Table 9. Ordinary Least Squares (OLS) Regression

\begin{tabular}{llll}
\multicolumn{4}{c}{ MatRelevance (OLS) } \\
\hline TotalAssets & $1.379^{*}(0.723)$ & StakeEngage & $8.056^{* * *}(1.357)$ \\
ROA & $12.045(29.148)$ & ESI & $-7.429^{*}(4.151)$ \\
Experience & $-2.205(1.773)$ & Intercept & $-13.569(10.341)$ \\
Assurance & $1.339(3.160)$ & Observation & 148 \\
GRIlevel & $2.237(1.733)$ & $\mathrm{F}$ & $5.10^{* * *}$ \\
IIRC & $0.253(1.037)$ & Adj. R2 & 0.32 \\
$* \mathrm{p}<0.10$ & & & \\
$* * \mathrm{p}<0.05$ & & & \\
$* * * \mathrm{p}<0.01$ & & &
\end{tabular}

